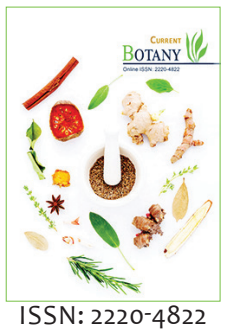

Received: November 23, 2019

Revised: March 03, 2020

Accepted: April 04, 2020

Published: April 04, 2020

*Corresponding Author:

Sape Subba Tata

Email:s_tata_s@yahoo.co.in

\section{Development of a profused In vitro shoot multiplication using leaf explants of Bacopa monnieri (L.) Pennell}

\author{
Sape Subba Tata* \\ Department of Botany, Andhra University, Visakhapatnam- 530003, Andhra Pradesh, India
}

\begin{abstract}
Bacopa monnieri (L.) Pennell is an important medicinal plant used for the preparation of medhyarasayan (rasayana). Leaf explants of field grown young plants of B. monnieri was used to establish an efficient regeneration protocol with cytokinin (BAP) and auxin (IAA). The highest multiplication, i.e. (220 shoots/leaf, a cumulative of 2200 shoots from 10 explants) were noticed after 45 days of culture in MS medium supplemented with BAP $(1.5 \mathrm{mg} / \mathrm{L})$ and IAA $(0.5 \mathrm{mg} / \mathrm{L})$. The optimum concentration of growth regulator for shoot elongation and rooting was recorded in MS+GA $(0.25 \mathrm{mg} / \mathrm{L})$ and MS+IBA $(1.5 \mathrm{mg} / \mathrm{L})$ respectively. The rooted plantlets were successfully established in green house conditions.
\end{abstract}

KEYWORDS: Brahmi, Leaf, Medhyarasayan, Multiple shoots

\section{INTRODUCTION}

Bacopa monnieri (L.) Pennell belongs to the family Scrophulariaceae, in India it is popularly known as 'Brahmi' and is used in Ayurveda for the preparation of medhyarasayan a drug used to improve intelligence and memory. It is the second most important medicinal plant among the list of the most important Indian medicinal plants assessed on the basis of their medicinal importance, commercial value and potential for future research and development [1]. It has a great commercial market value due to its high medicinal importance and shows a majority of pharmacological activities viz., antipyretic, antiinflammatory, analgesic, asthma, epilepsy, insanity, anticancer, antioxidant activities, blood clearing, hoarseness, memory enhancement, water retention etc., have been documented by many researchers $[2,3,4]$. It contains different types of terpenoid secondary metabolites i.e. bacosides A, B, C and D which are popularly known as "memory enhancers" $[5,6]$. It has been enlisted among 178 species of medicinal plants of India with high trade requirement ( $\geq 100$ million tonnes/ year). Unfortunately, the requirement of this plant material is fulfilled mainly by collection from the wastelands [7]. Due to the unsustainable collection of raw material from natural habitats it is already placed under threatened category [8]. The propagation of $B$. monnieri is generally through seeds and vegetative cuttings, but both the routes are not suitable for pilot scale production of Bacopa biomass due to its seeds have short viability and shows poor germination $[9,10]$. On the other hand the vegetative propagation through stem cuttings is a very slow process and depends on environmental, seasonal changes $[11,12]$. Hence, the conventional method of propagation is inadequate to meet the demand of raw material of B. monnieri. By over viewing the present status of drastic depletion of B. monnieri many laboratories are being given special attention to adopt micropropagation systems for rapid multiplication of this threatened medicinal plant species. The application of plant tissue culture in ex-situ conservation of medicinal plants is emphasized in many reports [13-16]. Keeping in mind the present status and pharmaceutical importance of the Bacopa, the present study was aimed to develop a rapid and efficient in vitro regeneration protocol from leaf explants of Bacopa, further, which can be useful in conservation and propagation of elite plants for commercial exploitation of this important medicinal plant.

\section{MATERIALS AND METHODS}

\section{Explant Preparation}

The leaf explants of B. monnieri were collected from the Botany Experimental Farm, Andhra University, Visakhapatnam, Andhra Pradesh, India. Then was surface sterilized with $0.1 \%$ $\mathrm{HgCl}_{2}$ and repeatedly washed in sterile distilled water and were transferred on to the various culture media for in vitro response.

Copyright: $\odot$ The authors. This article is open access and licensed under the terms of the Creative Commons Attribution License (http://creativecommons.org/licenses/by/4.0/) which permits unrestricted, use, distribution and reproduction in any medium, or format for any purpose, even commercially provided the work is properly cited. Attribution - You must give appropriate credit, provide a link to the license, and indicate if changes were made. 


\section{Micropropagation}

The basal MS medium [17] was used with different concentrations of cytokinin BAP (6-benzyl aminopurine) and auxin IAA (indole -3-acetic acid) and subculture at every 15 days on the same media. The number of shoot buds were recorded after third subculture, then the shoot buds was elongated on MS media with various levels of $\mathrm{GA}_{3}(0.10-0.30 \mathrm{mg} / \mathrm{L})$ after two weeks of culture. To test their rooting capacity, the in vitro elongated shoots were excised and transferred on to MS media supplemented with various concentrations of IBA $(0.5-2.5 \mathrm{mg} / \mathrm{L})$. The efficiency of rhizogenesis i.e., frequency of rooting (\%), root length $(\mathrm{cm})$ per shoot and number of roots per shoot were recorded after two weeks of culture. Each experiment consisted of 10 replicates.

\section{In vitro Conditions}

All media were supplemented with $3 \%(\mathrm{~W} / \mathrm{V})$ sucrose and $0.8 \%$ agar, the $\mathrm{pH}$ of the media was adjusted to 5.8 with $1 \mathrm{~N} \mathrm{NaOH}$ or $1 \mathrm{~N} \mathrm{HCl}$ prior to autoclaving. The cultures were maintained at temperature $25 \pm 2^{\circ} \mathrm{C}$ in the culture room with a 16 hours photoperiod under an illumination of $20 \mathrm{~m} \mathrm{~mol} \mathrm{~m}^{-2} \mathrm{~s}^{-1}$ photosynthetic photon flux density, provided by cool-white fluorescent light.

\section{Acclimatization}

The rooted plants were removed from the culture medium, washed in running tap water to remove the remains of agar and transferred to plastic pots containing sterilized vermiculate. They were hardened for four weeks at temperature $25 \pm 2{ }^{\circ} \mathrm{C}$ under low humidity and transplanted to clay pot containing sand and soil (1:1) and were maintained in green house conditions.

\section{RESULTS AND DISCUSSION}

In vitro propagation has been advocated as one of the most viable biotechnological tools for ex-situ conservation of rare, endangered and medicinally important plant species for future perspectives [18-20]. In the present study, we established an efficient regeneration system in leaf explants of B. monnieri. The leaf explants has started growth and producing multiple shoot initiation directly from the cut ends after two weeks of culture on MS medium supplemented with various levels of cytokinin $\operatorname{BAP}(0.5-3.0 \mathrm{mg} / \mathrm{L})$ in combination with auxin $\mathrm{IAA}(0.5 \mathrm{mg} / \mathrm{L}$ or $1.0 \mathrm{mg} / \mathrm{L})$. The results revealed that all the tested media were effective in inducing direct regeneration. Hence, all the respondent leaf cultures were maintained in the same media for three consecutive subcultures. Produced a total of 2200 shoots per ten leaf explants and a mean of $220.16 \pm 0.18$ shoots per leaf explants with 100 per cent shooting was recorded in the medium MS+BAP $(1.5 \mathrm{mg} / \mathrm{L})+\mathrm{IAA}(0.5 \mathrm{mg} / \mathrm{L})$ while, 200 shoots per ten explants and an average of $28.12 \pm 0.15$ shoots per explant was noticed in the medium MS+BAP $(3.0 \mathrm{mg} / \mathrm{L})+\mathrm{IAA}(1.0 \mathrm{mg} / \mathrm{L})$ after 45 days of culture (Table 1 and Fig. 1). To my knowledge, i have established the protocol for rapid and superior production of multiple shoots to reproduce B. monnieri using leaf explants

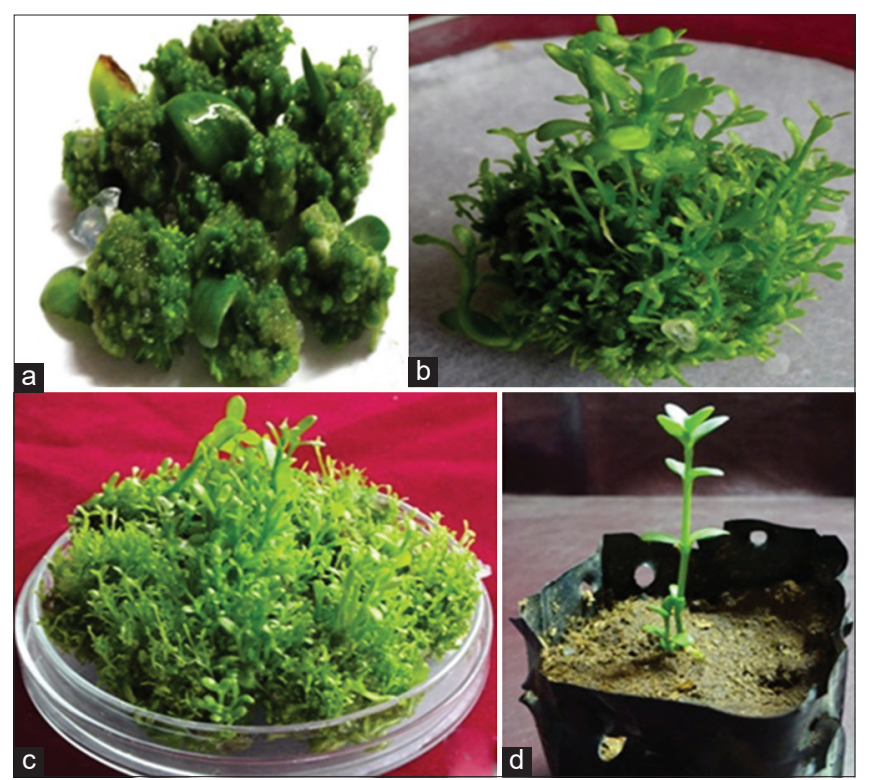

Figure 1: In vitro regeneration of Bacopa monnieri using leaf explants: a) leaf explants showing multiple shoot initiation; b) Proliferation of multiple shoots; c) profuse multiple shoot clusters developed after 45 days of culture; d) acclimatized plant

Table 1: Multiple shoot induction from leaf explants of Bacopa monnieri on different levels of BAP and IAA with MS medium

\begin{tabular}{lcccc}
\hline S. No. & BAP $(\mathrm{mg} / \mathrm{L})$ & IAA(mg/L) & \multicolumn{2}{c}{ Response } \\
\cline { 3 - 5 } & & & \% of Shooting* & Shoot no./Leaf* \\
\hline 1. & 0.0 & 0.0 & $00.00 \pm 0.00$ & $00.00 \pm 0.00$ \\
2. & 0.5 & 0.5 & $76.80 \pm 0.19$ & $98.00 \pm 0.14$ \\
3. & 1.0 & 0.5 & $88.50 \pm 0.12$ & $148.12 \pm 0.20$ \\
4. & 1.5 & 0.5 & $100.00 \pm 0.00$ & $220.16 \pm 0.18$ \\
5. & 2.0 & 0.5 & $80.30 \pm 0.20$ & $165.13 \pm 0.11$ \\
6. & 2.5 & 0.5 & $75.80 \pm 0.20$ & $85.18 \pm 0.09$ \\
7. & 3.0 & 0.5 & $66.50 \pm 0.10$ & $48.20 \pm 0.16$ \\
8. & 0.5 & 1.0 & $28.20 \pm 0.22$ & $30.14 \pm 0.23$ \\
9. & 1.0 & 1.0 & $52.50 \pm 0.15$ & $48.19 \pm 0.17$ \\
10. & 1.5 & 1.0 & $68.10 \pm 0.23$ & $75.14 \pm 0.10$ \\
11. & 2.0 & 1.0 & $62.40 \pm 0.18$ & $92.21 \pm 0.22$ \\
12. & 2.5 & 1.0 & $55.30 \pm 0.25$ & $86.12 \pm 0.18$ \\
13. & 3.0 & 1.0 & $38.80 \pm 0.24$ & $28.12 \pm 0.15$ \\
\hline
\end{tabular}

* Mean \pm SE of 10 replicates

over the earlier reports on Bacopa leaf explants, they reported the shoot number ranging from 3.4 to 138.9 per explant [21-32]. An overview of all the results in the present study, noticed that maximum induction of multiple shoots took place on MS medium fortified with various concentrations of BAP with low concentration of IAA. Similar findings also observed by a few researchers [33-36]. This may be due to the synergistic effect of cytokinin (BAP) and auxin (IAA) has been demonstrated in many medicinal plants, for example Santolina canescens [37], Bupleurum fruticosum [38] and turmeric [39] who noticed that the low concentrations of an auxin in combination with a cytokinin influence the frequency of shoot induction and growth effectively on the other hand the high concentration of cytokinin induced the formation of stunted shoots has been observed [40,41]. The microshoots with an average length at $1.0-1.5 \mathrm{~cm}$ were excised from the multiple shoot cluster 
Table 2: In vitro shoot elongation of Bacopa monnieri on various concentrations of $\mathrm{GA}_{3}$ with $\mathrm{MS}$ medium

\begin{tabular}{lcc}
\hline S.No. & $\mathrm{GA}_{3}(\mathrm{mg} / \mathrm{L})$ & Shoot length $(\mathrm{cm})^{*}$ \\
\hline 1. & 0.0 & $2.0 \pm 0.08$ \\
2. & 0.10 & $2.8 \pm 0.14$ \\
3. & 0.15 & $3.0 \pm 0.09$ \\
4. & 0.20 & $5.2 \pm 0.18$ \\
5. & 0.25 & $8.3 \pm 0.15$ \\
6. & 0.30 & $4.5 \pm 0.20$ \\
\hline
\end{tabular}

* Mean \pm SE of 10 replicates

Table 3: In vitro rooting of Bacopa monnieri on different concentrations of auxin IBA with MS medium

\begin{tabular}{llccc}
\hline S.No. IBA & \multicolumn{4}{c}{ Response } \\
\cline { 3 - 5 } & $(\mathrm{mg} / \mathrm{L})$ & Root induction (\%)* & Root no. $/$ shoot* & Root length $(\mathrm{cm})^{*}$ \\
\hline 01. & 0.0 & $00.0 \pm 0.00$ & $00.0 \pm 0.00$ & $0.0 \pm 0.00$ \\
02. & 0.5 & $65.10 \pm 0.13$ & $10.20 \pm 0.11$ & $6.20 \pm 0.09$ \\
03. & 1.0 & $77.30 \pm 0.18$ & $12.18 \pm 0.14$ & $8.00 \pm 0.17$ \\
04. & 1.5 & $100.00 \pm 0.00$ & $15.22 \pm 0.10$ & $9.50 \pm 0.09$ \\
05. & 2.0 & $69.20 \pm 0.15$ & $9.20 \pm 0.21$ & $7.10 \pm 0.18$ \\
06. & 2.5 & $58.24+0.22$ & $6.40 \pm 0.18$ & $5.20 \pm 0.22$ \\
\hline
\end{tabular}

* Mean \pm SE of 10 replicates

and transferred individually on MS medium fortifying with different levels of $\mathrm{GA}_{3}(0.1$ to $0.3 \mathrm{mg} / \mathrm{L}$ ) for elongation (Table 2). The higher shoot elongation (i.e., $8.3 \pm 0.15 \mathrm{~cm}$ per shoot) was noticed on MS medium containing $\mathrm{GA}_{3}(0.25 \mathrm{mg} / \mathrm{L})$. This may be due to the cell elongation roll of $\mathrm{GA}_{3}$ [42]. The elongated shoots raised in vitro failed to develop roots in MS basal medium. However, root initiation was achieved from the bases of excised shoots in the presence of various concentrations of IBA two weeks of transfer. Rooting response have been varied with the concentrations of IBA used (Table 3). Among these concentrations of IBA, MS medium containing IBA $(1.5 \mathrm{mg} / \mathrm{L})$ produced maximum response i.e. rooting frequency $(100 \%)$, root number $(15.22 \pm 0.10$ per shoot$)$ and root length $(9.50 \pm 0.09 \mathrm{~cm}$ per shoot). These results are agreed with the previous findings of Jain et al. [43]. Rooted plants were transplanted to green house condition after hardening showed $96 \%$ of survival. No detectable variations i.e., (growth and morphological characteristics) weren't observed in the acclimatized plants.

\section{CONCLUSIONS}

The output of the research meets the objectives of the present study and reports a rapid and efficient multiple shoot regeneration of leaf explants of B. monnieri with cytokinin (BAP) and auxin (IAA). Further, the results of the study can be helpful in future production of true to the type clonally multiplied plants for pilot scale pharmacological use.

\section{ACKNOWLEDGEMENTS}

The author Subba Tata is grateful to Prof. O. Aniel Kumar and UGC-SAP-CAS-I, Department of Botany, Andhra University for providing financial assistance.

\section{REFERENCES}

1. Anonymous (1997). Indian medicinal plants: A sector study. Occasional paper No. 54. Export-Import Bank of India, Quest publications, Bombay, India.

2. Satyavati GV, Raina MK, Sharma M (1976). Indian medicinal plants. Vol. 1, Indian Council of Medical Research, New Delhi, pp.20-35.

3. Jain P, Kulshreshtha DK (1993). Bacoside Al, a minor saponin from Bacopa monnieri. Phytochemistry 33:449-451.

4. Sinha S, Saxena R (2006). Effect of iron on lipid peroxidation and enzymatic and non enzymatic antioxidant and bacosides - a content in medicinal plant Bacopa monnieri L., Chemosphere 62:1340-1350.

5. Rastogi S, Pal R, Kulshreshtha DK (1994). Bacoside A3 - a triterpenoid saponin from Bacopa monnieri. Phytochemistry 36(1):133-137.

6. Sivaramakrishna C, Rao CV, Trimurtulu G, Vanisree M, Subbaraju GV (2005). Triterpenoid glycosides from Bacopa monnieri. Phytochem 66(23):2719-2728.

7. Ved DK, Goraya GS (2007). Demand and Supply of Medicinal Plants in India. NMPB, New Delhi and FRLHT, Bangalore, India.

8. Ceasar SA, Maxwell SL, Prasad KB, Karthigan M, Ignacimuthu S (2010). Highly efficient shoot regeneration of Bacopa monnieri (L.) using a two-stage culture procedure and assessment of genetic integrity of micropropagated plants by RAPD. Acta Physiol Plant 32:443-452.

9. Tiwari V, Tiwari KN, Singh BD (2001) Comparative studies of cytokinins on in vitro propagation of Bacopa monnieri. Plant Cell, Tissue and Organ Culture 66(1):9-16.

10. Rathore S, Singh N (2013). In vitro conservation of Bacopa monnieri - an endangered medicinal plant. Global J Bio Sci Biotechnol 2(2):187-192

11. Shah JD (1965). Studies in growth and ecology of Bacopa monnieri (L.) Pennell.- a medicinal herb. Ph.D. Thesis, Banaras Hindu University, Varanasi, India.

12. Sharma N (2005). Micropropagation of Bacopa monnieri L. Penn.- an important medicinal plant. M.Phil. Thesis. Thapar Institute of Engineering and Technology Patiala, India.

13. Arora R, Bhojwani SS (1989). In vitro propagation and low temperature storage of Saussurea lappa C.B. Clarke - an endangered, medicinal plant. Plant Cell Reports 8:44-47.

14. Purohit SD, Dave A, Kukda G (1994). Micropropagation of safed musli (Chlorophytum borivilianum), a rare Indian medicinal plant. Plant Cell Tissue and Organ Culture 39:93-96.

15. Kasagana VN, Swathi SK (2011). Conservation Of Medicinal Plants (Past, Present \& Future Trends). Journal of Pharmaceutical Sciences and Researh, 3(8):1378-1386.

16. Attia OA, Dessoky SED, Yassin MA, Ismail Al (2018). Ex situ preservation for some endemic and rare medicinal plants in Taif, KSA. Biotechnology \& Biotechnological Equipment, 31(5):912-920.

17. Murashige T, Skoog K (1962). A revised medium for rapid growth and bioassay with tobacco tissue cultures. Physiology Plant 15:473-497.

18. Latto SK, Bamorta S, Dhar RS, Khan S, Dhar AK (2006). Rapid plant regeneration and analysis of genetic fidelity of in vitro derived plants of Chlorophytum arundinaceum Baker-an endangered medicinal herb. Plant Cell Rep 25:499-506.

19. Joshi P, Dhawan V (2007). Axillary multiplication of Swertia chirayita (Roxb. Ex Fleming) H. Karst., a critically endangered medicinal herb of temperate Himalayas. In Vitro Cell Dev Biol Plant 43:631-638.

20. Sivanesan I (2007). Direct regeneration from apical bud explants of Withania somnifera Dunal. Indian J Biotechnol 16:125-127.

21. Binita B, Ashok, DM, Yogesh JT (2005). Bacopa monnieri (L) Pennell: A rapid, efficient and Cost effective micropropagation; Plant Tissue Cult Biotechnol 15(2):167-175.

22. Mohapatra HP, Rath SP (2005). In vitro studies of Bacopa monnieri: An important medicinal plant with reference to its biochemical variations. Indian J Exp Biol 43(4):373-376.

23. Sharath R, Krishna V, Sathyanarayana BN, Maruthi Prasad BN, Harish BG (2007). High Frequency regeneration through somatic embryogenesis in Bacopa monnieri (L.) Wettest. Medicinal and Aromatic Plant Science and Biotechnology 1(1):138-141.

24. Praveen N, Naik PM, Manohar SH, Nayeem A, Murthy HN (2009). In vitro regeneration of Brahmi shoots using semi solid and liquid cultures and quantitative analysis of Bacoside-A. Acta Physiol Plantarum 31(4):723-728.

25. Joshi AG, Pathak AR, Sharma AM, Singh S (2010). High frequency 
of shoot regeneration on leaf explants of Bacopa monnieri. Environmental and Experimental Biology 8:81-84.

26. Vijayakumar M, Vijayakumar R, Stephen R (2010). Invitro propagation of Bacopa monnieri L. - a multipurpose medicinal plant. Indian Journal of Science and Technology, 3(7):781-786.

27. Tanveer A, Khan M, Shah F (2010). In vitro Micropropagation of Brahmi - Bacopa monnieri (L.) Pennell - A Step for Conservation. Nanobiotechnica Universale 1(2):139-150.

28. Srinath Rao, Rajkumar P, Kaviraj C, Asra Parveen P (2012). Efficient plant regeneration from leaf explants of Bacopa monniera (L.) Wettst.: A threatened medicinal herb. Annals of Phytomedicine 1(1):110-117.

29. Anuja K, Arti S, Sofia G, Sharada M (2014). Cost effective protocol for micropropagation of Bacopa monnieri using leaf explants. International Journal of Science and Research 3(4):210-212.

30. Sheikh SS, Dakhane VP, Chaudhary AD (2015). Callus Induction in Bacopa monnieri (L.) Pennell by Nodal, Internodal, Young and Mature Leaf Explants. Int Journal of Res. In Biosciences, Agriculture \& Technology 1:101-108.

31. Priya Dharishini M, Krishna moorthy M, Balasubramanian K (2015). Effects of Plant Growth Regulators and Activated Charcoal on Regeneration and Plantlet Development in Neer Brahmi (Bacopa monnieri). Journal of Academia Industrial Research 4(2):69-74.

32. Anita Mehta (2017). Effect of plant growth regulators on callus multiplication and in vitro plant regeneration in Bacopa monnieri L. International Journal of Medicinal Plants Research 6(5):337-345.

33. Joshi A, Kothari SL (2007). High copper levels in the medium improves shoot bud differentiation and elongation from the cultured cotyledons of Capsicum annuum L. Plant Cell, Tissue Organ Culture 88:127-133.

34. Rahman MT, Hossain MJ, Khalekuzzaman M (2008). In vitro indirect plantlet regeneration from hypocotyl segments and cotyledonary explant derived calli in lady's finger (Abelmoschus esculentus Monech). J Bio Sci 16:49-57.

35. Ashrafuzzaman M, Hossain M, Razi IM, Shahidul M, Haque M, Shahidullah SM, Shahin UZ (2009). Regeneration potential of seedling explants of chilli (Capsicum annuum). Afr J Biotechnol 8:591-596.

36. Otroshy M, Moradi K, Nekouei MK, Struik PC (2011). Micropropagation of pepper (Capsicum annuum L.) through in vitro direct organogenesis. Asian J Biotechnol 3:38-45.

37. Casado JP, Navarro MC, Utrilla MP, Martinez A, Jimenez J (2002). Micropropagation of Santolina canescens Lagasca and in vitro volatiles production by shoot explants. Plant Cell, Tissue Organ Culture 69:147-153.

38. Fraternale D, Giamperi L, Ricci D, Rocchi MBL (2002). Micropropagation of Bupleurum fruticosum: the effect of triacontanol. Plant Cell, Tissue Organ Culture 69:135-140.

39. Salvi ND, George L, Eapen S (2002). Micropropagation and field evaluation of micropropagated plants of turmeric. Plant Cell, Tissue Organ Culture 68:143-151.

40. Tavarea AC, Pimenta MC, Goncalves MT (1996). Micropropagation of Melissa officinalis L. through proliferation of axillary shoots. Plant Cell Rep 115:441-444.

41. Koroch AR, Hector RJ, Victorio ST (1997). Micropropagation and acclimatization of Hedeoma multiflorum. Plant Cell, Tissue Organ Culture 48:213-217.

42. Cin C, Dong Z, Liu W, Deng Z, Tang L (2005). Effects of exogenous plant growth regulator on in vitro regeneration of cotyledon explants in pepper. Not Bot Hort Agrobot Cluj 13:25-32.

43. Jain R, Prasad B, Jain M (2013). In vitro regeneration of Bacopa monnieri (L.): A highly valuable medicinal plant. Int J Curr Microbiol App Sci 2(12):198-205 